factors on the lakes of Volyn region. The differentiation of groups and types of lakes of Turiysk district, based on the current European criteria, is conducted. The possible solutions of the problem are considered with the aim of preceding the hydrological role of reservoirs. Taking into account the necessity of land reclamation complex measures the estimation of natural resources of lake ecosystems is executed. The explored supplies and quality of bottom sediments are indicated and the state of coastal and riverside is described. The natural protected features of areas, kinds of plants and animals listed in the Red Book are indicated. The legislative regulation of business activity on the protected areas is analyzed and the most effective ways of lake sediments application for various types of economic activity are offered.

Key words: lake, basin, directive, typology, sapropel.

\title{
Екологічний аспект просторової неоднорідності едафотопів техногенного походження
}

Досліджено динаміку просторової неоднорідності педозему ділянки рекультивації Нікопольського марганцеворудного басейну в м Орджонікідзе за показниками твердості. Проведено екоморфічний аналіз рослинності ділянки. Методом неметричного багатовимірного шкалювання здійснено ординацію даних твердості грунту. Застосовано тривимірний варіант багатовимірного шкалювання. Виділено характерні для вивченого грунту типи розподілу твердості за профілем. Взаємозв'язок варіювання твердості грунту й факторів навколишнього середовища встановлено при використанні фітоіндікаційних шкал. За допомогою техніки просторового аналізу даних (PCNM) виділено просторові структури на різних масштабних рівнях і визначено процеси, що лежать у їх основі.

Ключові слова: твердість грунту, екоморфічний аналіз, педозем, багатовимірне шкалювання.

Постановка наукової проблеми та її значення. Існування закономірної неоднорідності грунтів на невеликих відстанях $є$ доказом множинності будови і властивостей грунтів та наслідком різноспрямованої дії факторів грунтоутворення й особливо складних і суперечливих взаємозв’язків грунтового тіла з рослинністю та кліматом $[13,17,19]$. Видима просторова структура проявляється на різних масштабних рівнях і $€$ результатом причин абіотичного, біологічного й історичного характеру, що доповнюють одна іншу [28, 29]. Просторова неоднорідність грунтів порушених промисловістю земель є актуальним предметом наукових досліджень у зв'язку зі зростаючою інтенсивністю антропогенного пресу та питаннями господарського призначення порушених територій [4].

Виходячи із закону єдності «організм-середовище», за В. І. Вернадським, життя розвивається в сукупній єдності середовища й організмів, що іiі населяють. Відносини організму та середовища $є$ системними, у них діє принцип екологічної відповідності: форма існування організму завжди відповідає умовам життя $[5,19]$. Установлено, що судинні рослини проявляють свій біоекологічний потенціал в екстремальних умовах техногенного середовища, пристосовуючись до нього відповідно до своїх біологічних й екологічних особливостей. У техногенних екотопах зростання, розвиток і зовнішній вигляд рослин залежать від того, наскільки відповідають екологічні умови місцеперебування вимогам тих чи інших видів. Взаємозв'язок між фізико-хімічними характеристиками субстратів і процесами сінгенезу рослинності на едафотопах техногенного походження дає можливість використовувати фітокомпоненту як інтегральний показник стану техногенних екотопів та біогеоценозів, що формуються [5]. Функціональна цілісність біогеоценозу передбачає, що грунт повинен проявляти морфологічно й функціонально свою відповідність іншим його компонентам. Показником грунтових властивостей, що має інтегральність і високу інформативність, є твердість грунту [15]. Варіювання твердості грунту в просторі достовірно корелює 3 такими показниками, як проективне покриття, фітомаса, агрегатний склад верхнього шару грунту і його електропровідність [3, 10, 11]. Твердість грунту є лімітуючим фактором для рослинного покриву. Глибина виникнення граничної твердості бере участь у формуванні ділянки екологічного простору з найбільшими продукційними характеристиками, а наближення порогової твердості до поверхні грунту пов’язане зі зміною видового багатства досліджуваного рослинного угрупування.

(C) Задорожна Г., 2016 
Мета дослідження - 3'ясування впливу факторів навколишнього середовища на формування неоднорідності рекультиваційних грунтів за показниками твердості.

Матеріали й методи дослідження. Збір матеріалу проводили в червні 2013 р. на ділянці рекультивації Нікопольського марганцеворудного басейну в м. Орджонікідзе. Експериментальну ділянку з вивчення оптимальних режимів сільськогосподарської рекультивації утворили в 1968-1970рp. на зовнішньому відвалі Запорізького марганцеворудного кар'єру. На цій ділянці створено штучні едафотопи двох типів. Перший являє собою сплановані розкривні породи товщиною 2 м, які винесені з різних глибин. Другий - на спланованій суміші розкривних порід із відсипанням на їхню поверхню різних за потужністю шарів чорноземної маси. Об'єктом цього дослідження обрано педозем із товщою насипного шару 50 см. Назву грунту наведено за Л. В. Стеревською [7]. Сьогодні тип рослинності представлений бобово-злаковою сумішшю й різнотрав'ям.

Дослідний полігон являє собою регулярну сітку, яка складається з точок відбору проб, відстань між якими - 3 м, із семи трансект по 15 проб. Відповідно, його розміри становлять 42 м × 18 м.

Вимірювання твердості грунту проведені в польових умовах за допомогою ручного пенетрометра Eijkelkamp на глибині до 50 см з інтервалом 5 см. Основною робочою частиною твердоміра $€$ плунжер, нагвинчений на нижній кінець штока, який за допомогою рукоятки через пружину заштовхується в досліджений грунт. При цьому пружина, що вимірює, стискається пропорційно до величини опору деформації грунту [12]. Середня похибка результатів вимірювань прилада складає $\pm 8 \%$.

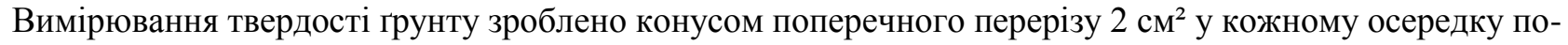
лігону.

Фітоіндікаціонні шкали наведено за Я. П. Дідухом [28], ценоморфи рослин - за А. Л. Бельгардом [2]. При статистичних розрахунках використано методи описової статистики. Для зниження розмірності простору показників твердості грунту застосовано неметричне багатовимірне шкалювання.

Виклад основного матеріалу й обгрунтування отриманих результатів дослідження. Середні значення твердості грунту збільшуються з глибиною від 2,20 \pm 0,09 МПа на поверхні до 6,34 \pm 0,24 МПа на глибині 50 см униз за профілем. Коефіцієнт кореляції великий на поверхні $(41,4$ \%) знижується в шарах 5-25 см і знову зростає вглиб за профілем. Локальний максимум варіативності ознаки спостерігається в шарі 30-35 см нижче поверхні (44,4 \%) (табл. 1). Глибина, на якій у середньому трапляється твердість у 3 МПа, - на рівні $11,11 \pm 7,88$ см нижче поверхні. Коефіцієнт варіації цієї величини високий $-54,13$ \%. Згадана твердість, за даними науковців, $є$ критичною для росту коренів рослин [14]. При опорі грунту вище 3 МПа кореневий волосок не в змозі його подолати й припиняє своє зростання. Величина 11,11 см обмежує обсяг, у якому зосереджена основна маса коренів рослин вивченої ділянки.

Таблиия 1

Описові статистики твердості грунту

\begin{tabular}{|c|c|c|c|c|}
\hline \multirow{2}{*}{$\begin{array}{c}\text { Твердість грунту } \\
\text { на глибині }\end{array}$} & \multirow{2}{*}{ Середнє } & \multicolumn{2}{|c|}{ Довірчий інтервал } & \multirow{2}{*}{$\mathrm{CV}, \%$} \\
\hline & & $-95 \%$ & $+95 \%$ & \\
\hline \multicolumn{5}{|c|}{ Твердість трунту на глибині, МПа } \\
\hline $0-5 \mathrm{~cm}$ & $2,20 \pm 0,09$ & 2,02 & 2,37 & 41,4 \\
\hline $5-10 \mathrm{~cm}$ & $3,55 \pm 0,13$ & 3,29 & 3,81 & 38,1 \\
\hline $10-15 \mathrm{~cm}$ & $4,27 \pm 0,16$ & 3,95 & 4,58 & 37,8 \\
\hline $15-20 \mathrm{~cm}$ & $4,68 \pm 0,18$ & 4,33 & 5,02 & 38,4 \\
\hline $20-25 \mathrm{~cm}$ & $4,74 \pm 0,17$ & 4,39 & 5,04 & 35,9 \\
\hline $25-30 \mathrm{~cm}$ & $5,17 \pm 0,21$ & 4,76 & 5,58 & 40,9 \\
\hline $30-35 \mathrm{~cm}$ & $5,69 \pm 0,25$ & 5,20 & 6,18 & 44,4 \\
\hline $35-40 \mathrm{~cm}$ & $5,92 \pm 0,25$ & 5,43 & 6,41 & 42,7 \\
\hline $40-45 \mathrm{~cm}$ & $6,07 \pm 0,25$ & 5,57 & 6,57 & 42,7 \\
\hline $45-50 \mathrm{~cm}$ & $6,34 \pm 0,24$ & 5,85 & 6,82 & 39,3 \\
\hline \multicolumn{5}{|c|}{ Глибина (см), із якої починається твердість трунту } \\
\hline $3 \mathrm{MПа}$ & $11,11 \pm 7,88$ & 9,58 & 12,63 & 54,13 \\
\hline
\end{tabular}


Для вивчення взаємозв'язку варіювання твердості грунту й організації рослинності застосовано екоморфічний аналіз [2]. Він побудований на використанні інформації про вимоги популяцій, що складають біогеоценоз, до параметрів середовища (температури, освітленості, поживних речовин, вологості). Завдяки своїй структурованості ця класична концепція природним чином може бути описана за допомогою мови математичної біології [27]. Установлено, що фітоіндикаційні шкали щодо грунтових властивостей мають більшу індикативність, ніж пряме вимірювання параметрів навколишнього середовища [11]. У нашому дослідженні вони виступають як зв’язуюча ланка між структурою рослинності й твердістю грунту.

Ординація даних твердості грунту проведена за допомогою неметричного багатовимірного шкалювання. Багато експертів визнають, що цей метод дає найадекватніші результати, особливо у великих блоках матеріалу із сильними шумами (випадковими відхиленнями) $[18,19,31,32,34]$. Суть його полягає в зниженні розмірності простору для відображення вихідного багатовимірного масиву даних. Для цього може бути обрана деяка міра, яка визначає відстань між розглянутими об'єктами. Алгоритм моделює розміщення точок у деякому n-вимірному просторі таким чином, щоб відстані між точками в n-вимірному просторі були якомога ближчі до відстаней, що визначені для m-мірного простору, де $\mathrm{m}$ - число об’єктів, що вивчаються. При цьому $\mathrm{n}$ - число координаційних осей, або шкал, - свідомо невелике, тобто $\mathrm{m}>\mathrm{n}$. У результаті кількість інформаційно-важливих вимірів стає меншою, а шкали отримують композиційні властивості [22].

У нашому випадку інформаційна цінність для діагностики факторів зовнішнього середовища переходить від даних твердості грунту як самостійних джерел інформації до осей екологічного простору. У процесі багатовимірного шкалювання ці осі відображаються вимірами.

Процедура передбачає обчислення рангової кореляції матриць дистанцій між сайтами вимірювання твердості та матриць дистанцій, установленими на основі факторів навколишнього середовища. Факторами навколишнього середовища в нашому дослідженні виступають оцінки едафотопу й кліматопу, виражені через фітоіндикаційні шкали.

Для отримання найбільшої рангової кореляції при проведенні неметричного багатовимірного шкалювання здійснюють вибір міри зв'язку між об'єктами, а також попереднє перетворення первинних даних [30]. Як заходи зв'язку використовують такі метрики, як евклідова, манхеттенська, Гувера, Брея-Куртиса, Кульчинського, Морисита, Горна-Морисита, Біноміальна, Као, Жаккара, Маунфорда, Рауп-Крика, Канберра, Чао [33]. Можливі такі варіанти перетворення даних: витяг логарифма, кореня квадратного, хі-квадрат перетворення, трансформація Хеллінджера й вісконсинська $[10,11]$.

У табл. 2 наведено результати обчислення кореляції Спірмена з матрицями дистанцій між сайтами відбору проб, установленими за даними виміру твердості грунту й матрицями дистанцій, знайденими на основі факторів навколишнього середовища. Аналіз отриманих даних свідчить про те, що найбільшою кореляцією з факторами середовища характеризується матриця на основі відстані Чао з показниками, попередньо стандартизованими до діапазону 0-1. При подальших обчисленнях експериментальні дані використовуватимуться в перетвореному цим способом вигляді.

Таблиия 2

Коефіціснти рангової кореляції Спірмена матриць мір відмінності-подібності між сайтами відбору проб за даними виміру твердості грунту й змінних навколишнього середовища

\begin{tabular}{|c|c|c|c|c|c|c|c|c|c|c|c|}
\hline \multirow{2}{*}{ Метрика } & \multicolumn{11}{|c|}{ Спосіб трансформації даних } \\
\hline & 1 & 2 & 3 & 4 & 5 & 6 & 7 & 8 & 9 & 10 & 11 \\
\hline 1 & 2 & 3 & 4 & 5 & 6 & 7 & 8 & 9 & 10 & 11 & 12 \\
\hline Евклидова & 0,10 & 0,13 & 0,12 & 0,07 & 0,11 & 0,12 & 0,06 & 0,11 & 0,09 & 0,08 & 0,09 \\
\hline Манхеттенська & 0,11 & 0,13 & 0,12 & 0,08 & 0,11 & 0,12 & 0,07 & 0,11 & 0,10 & 0,09 & 0,10 \\
\hline Гувера & 0,11 & 0,12 & 0,12 & 0,08 & 0,11 & 0,11 & 0,07 & 0,11 & 0,09 & 0,08 & 0,09 \\
\hline Брея-Куртиса & 0,10 & 0,12 & 0,11 & 0,08 & 0,11 & 0,11 & 0,07 & 0,10 & 0,10 & 0,09 & 0,10 \\
\hline Кульчинського & 0,10 & 0,12 & 0,11 & 0,08 & 0,11 & 0,11 & 0,07 & 0,10 & 0,10 & 0,09 & 0,10 \\
\hline Морисита & 0,01 & - & - & 0,01 & 0,00 & $-0,02$ & $-0,03$ & $-0,01$ & $-0,06$ & 0,01 & $-0,01$ \\
\hline Горна-Морисита & 0,06 & 0,12 & 0,09 & 0,06 & 0,09 & 0,10 & 0,06 & 0,08 & 0,09 & 0,08 & 0,09 \\
\hline
\end{tabular}


Закінчення табличі 2

\begin{tabular}{|l|c|c|c|c|c|c|c|c|c|c|c|}
\hline \multicolumn{1}{|c|}{$\mathbf{1}$} & $\mathbf{2}$ & $\mathbf{3}$ & $\mathbf{4}$ & $\mathbf{5}$ & $\mathbf{6}$ & $\mathbf{7}$ & $\mathbf{8}$ & $\mathbf{9}$ & $\mathbf{1 0}$ & $\mathbf{1 1}$ & $\mathbf{1 2}$ \\
\hline Као & 0,13 & 0,13 & 0,13 & 0,02 & 0,13 & 0,13 & 0,09 & 0,11 & 0,13 & 0,11 & 0,05 \\
\hline Жаккара & 0,10 & 0,12 & 0,11 & 0,08 & 0,11 & 0,11 & 0,07 & 0,10 & 0,10 & 0,09 & 0,10 \\
\hline Маунфорда & - & - & - & - & - & - & - & 0,08 & - & - & - \\
\hline Раупп-Крика & - & - & - & - & - & - & - & $-0,03$ & - & - & - \\
\hline Канберра & 0,12 & 0,13 & 0,13 & 0,12 & 0,12 & 0,12 & 0,11 & 0,13 & 0,12 & 0,12 & 0,12 \\
\hline Чао & - & - & - & - & - & - & - & $\mathbf{0 , 1 4}$ & - & - & - \\
\hline Махаланобиса & 0,08 & 0,10 & 0,10 & 0,04 & 0,08 & 0,08 & 0,04 & 0,08 & 0,08 & 0,04 & 0,04 \\
\hline
\end{tabular}

Умовні позначення: 1 - дані не трансформовані; 2 - логарифмовані дані; 3 - корінь квадратний; 4 - дані, поділені на маргінальну суму; 5 - дані, поділені на маргінальний максимум; 6 - дані, поділені на маргінальну суму й помножені на число ненульових значень; 7 - нормалізовані дані (маргінальна сума квадратів значень дорівнює 1); 8 - стандартизовано до діапазону 0-1; 9 - стандартизовані дані (середнє дорівнює 0, а варіація - 1); 10 - перетворення Хеллінджера; 11 - $\chi^{2}$-трансформація; 12 - вісконсинська трансформація.

Для визначення ступеня подібності між вихідною матрицею відстаней і відстанями між точками вводиться функція стресу. Стрес, рівний нулю, означає повну тотожність порівнюваних матриць. Завдання ординації зводиться до підбору таких координат точок у новому просторі, щоб величина стресу між модельною й емпіричною матрицями була мінімальною, а подібність матриць - максимальною.

Проведені розрахунки свідчать про те, що тривимірний варіант багатовимірного шкалювання достатній для точного відображення вихідного масиву даних твердості грунту, оскільки збільшення числа вимірювань вищезазначеного не призводить до істотного приросту точності відображення (рис. 1).

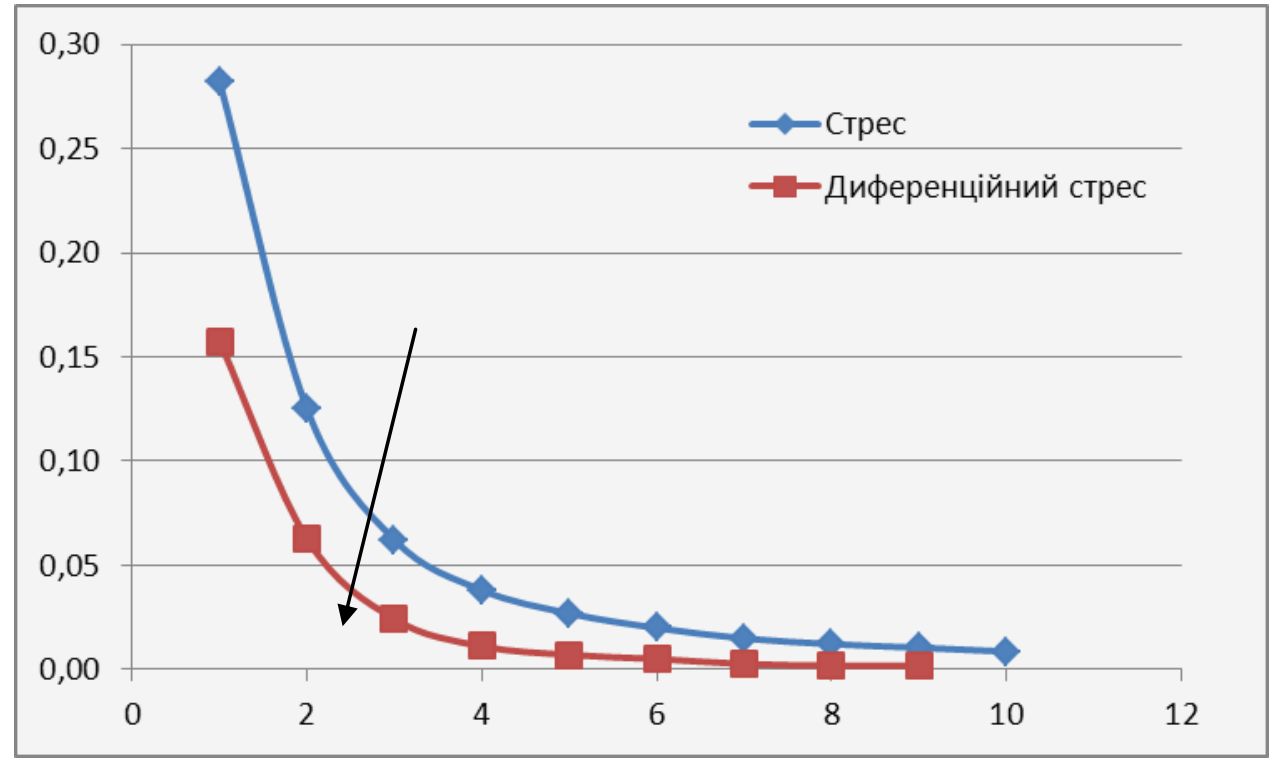

Рис. 1. Залежність диференційного стресу від числа вимірів

Умовні позначення: вісь абсцис - число вимірювань; вісь ординат - стрес (вісь ліворуч) і диференційний стрес (вісь праворуч); стрілкою вказана зона різкого перегину лінії диференційного стресу.

Інтерпретація знайдених вимірювань здійснюється на основі аналізу матриці середньозважених значень багатовимірних осей для показників твердості грунту (табл. 3).

Факторні ваги дають змогу ранжувати, упорядкувати об'єкти (якими в нашому випадку є твердість грунту на різних глибинах) по кожній багатовимірній шкалі, і побачити міру прояву вимірювання в окремого вихідного об'єкта. Чим більша факторна вага деякого об'єкта (за модулем), тим більше в ньому проявляється та сторона явища чи та закономірність, яку віддзеркалює цей фактор.

Багатовимірна вісь NMDS1 відокремлює блок високих за модулем значень факторних ваг, що відповідає шарам 30-50 см нижче поверхні й протиставляє їм значення шарів, розміщених вище від 
виділеного блоку. NMDS2 виділяє як найбільш значущу будову поверхневого шару (0-5 см) i відображає протилежні явища в організації грунту вище та нижче рівня 25 см від поверхні. Багатовимірна шкала NMDS3 маркує умови, що відрізняють твердість грунту на рівні 10-35 см профілю від решти товщі грунту з найбільш значущими вагами, відповідними поверхневому шару.

Таблиия 3

\section{Середньозважені значення багатовимірних осей для показників твердості грунту (факторні ваги)}

\begin{tabular}{|c|c|c|c|}
\hline \multirow{2}{*}{$\begin{array}{c}\text { Твердість грунту } \\
\text { на глибині }\end{array}$} & \multicolumn{3}{|c|}{ Багатомірні шкали } \\
\cline { 2 - 4 } & NMDS1 & NMDS2 & NMDS3 \\
\hline $0-5$ см & $-0,05$ & 0,28 & $-0,26$ \\
\hline $5-10$ cм & 0,23 & 0,18 & $-0,08$ \\
\hline $10-15$ cм & 0,12 & 0,19 & 0,07 \\
\hline $15-20$ cм & 0,09 & 0,16 & 0,11 \\
\hline $20-25$ cм & 0,03 & 0,04 & 0,17 \\
\hline $25-30$ см & 0,14 & $-0,01$ & 0,06 \\
\hline $30-35$ cм & $-0,30$ & $-0,07$ & 0,01 \\
\hline $35-40$ см & $-0,27$ & $-0,14$ & $-0,02$ \\
\hline $40-45$ см & $-0,32$ & $-0,18$ & $-0,04$ \\
\hline $45-50$ см & $-0,34$ & $-0,18$ & $-0,06$ \\
\hline
\end{tabular}

У табл. 4 відображено частку дисперсії досліджуваної ознаки, яка пояснена фітоіндикаційними шкалами, а також розподіл інформаційної значущості між багатовимірними осями.

Статистично значимі фітоіндикаційні шкали описують від шести до $10 \%$ варіабельності багатовимірних вимірів. Кожен вимір розподіляє досліджувані об'єкти вздовж деякого екологічного тренду, який можна інтерпретувати в термінах одного або декількох переважаючих корелятивних ознак. Ці тренди мають складну композитну природу й утворюють певну структуру, яка відображатиме найважливіші риси, що вивчаються. Така модель дає можливість обчислювати внески факторів зовнішнього середовища в загальну дисперсію досліджуваної ознаки: чим вища ця частка, тим більш значущим, важливим є фактор.

Багатовимірна вісь NMDS1 відображає зміни твердості грунту залежно від глибини залягання грунтового шару. Предикторів, які в першому вимірі враховують значну частку поясненої дисперсії, немає. Факторами, що визначають другу координаційну вісь, є шкала гідроморф (Hygr) та шкала сольового режиму $(\mathrm{Sl})$. Вони пов'язані таким чином, що протиставляють ступінь засолення ступеню зволоження едафотопу. Також високою пояснювальною здатністю володіє шкала аерації грунту та присутності в рослинному угрупуванні степантів (St). Найбільш високе значення у формуванні NMDS3 має шкала освітлення (Lc). Наступними за значимістю внесками у формування цього виміру відзначаються шкали сольового режиму, гідроморф, степантів.

Таблиия 4

Частка дисперсії осей, яка пояснена фітоіндикаційними шкалами, і розподіл інформаційної значущості між багатовимірними шкалами

\begin{tabular}{|c|c|c|c|c|c|c|}
\hline $\begin{array}{c}\text { Фітоіндикаційні } \\
\text { шкали }\end{array}$ & NMDS1 & NMDS2 & NMDS3 & $\boldsymbol{r}^{2}$ & $\operatorname{Pr}(>\mathbf{r})$ & $\begin{array}{c}\text { Коди } \\
\text { значущості }\end{array}$ \\
\hline $\mathbf{1}$ & $\mathbf{2}$ & $\mathbf{3}$ & $\mathbf{4}$ & $\mathbf{5}$ & $\mathbf{6}$ & $\mathbf{7}$ \\
\hline $\mathrm{Hd}$ & $-0,27$ & 0,77 & $-0,57$ & 0,04 & 0,28 & \\
\hline $\mathrm{ffl}$ & 0,17 & 0,92 & 0,35 & 0,05 & 0,18 & \\
\hline $\mathrm{Rc}$ & $-0,35$ & $-0,11$ & 0,93 & 0,05 & 0,19 & \\
\hline $\mathrm{Sl}$ & $-0,07$ & $-0,41$ & 0,91 & 0,07 & 0,04 & $*$ \\
\hline $\mathrm{Ca}$ & $-0,57$ & 0,10 & 0,82 & 0,03 & 0,41 & \\
\hline $\mathrm{Nt}$ & 0,02 & $-0,34$ & $-0,94$ & 0,01 & 0,72 & \\
\hline $\mathrm{Ae}$ & $-0,20$ & $-0,97$ & $-0,16$ & 0,07 & 0,07 & \multirow{2}{}{} \\
\hline $\mathrm{Tm}$ & $-0,50$ & $-0,57$ & $-0,65$ & 0,03 & 0,44 & \\
\hline $\mathrm{Om}$ & $-0,45$ & $-0,88$ & $-0,13$ & 0,03 & 0,34 & \\
\hline $\mathrm{Kn}$ & 0,25 & 0,37 & 0,89 & 0,04 & 0,25 & \\
\hline
\end{tabular}


Закінчення таблиці 3

\begin{tabular}{|c|c|c|c|c|c|c|}
\hline $\mathbf{1}$ & $\mathbf{2}$ & $\mathbf{3}$ & $\mathbf{4}$ & $\mathbf{5}$ & $\mathbf{6}$ & $\mathbf{7}$ \\
\hline Cr & $-0,18$ & $-0,68$ & $-0,71$ & 0,06 & 0,14 & \\
\hline Lc & $-0,08$ & $-0,13$ & 0,99 & 0,08 & 0,04 & $*$ \\
\hline Hygr & 0,01 & $-0,72$ & 0,69 & 0,10 & 0,02 & $*$ \\
\hline Troph_B & $-0,32$ & 0,10 & $-0,94$ & 0,05 & 0,14 & \\
\hline St & $-0,04$ & 0,66 & $-0,75$ & 0,06 & 0,10 &, \\
\hline Pr & 0,05 & $-0,66$ & 0,75 & 0,06 & 0,11 & \\
\hline Hel & 0,24 & 0,58 & 0,78 & 0,03 & 0,37 & \\
\hline
\end{tabular}

Примітка. Коди значущості: ‘*’ - < 0,05; Hd - шкала гідроморф, ffl - змінність зволоження, Rc - режим кислотності, Sl - сольовий режим, Са - уміст карбонатних солей, $\mathrm{Nt}$ - зміст засвоюваних форм азоту, Ае аерація, Tm - терморежим, Om - омброрежим, Kn - континентальність клімату, Cr - кріорежим, Lc - шкала освітлення, Hyg - гігроморфи, Troph_B - трофоморфи; St - степанти, Pr - пратанти, Hel - геліоморфи.

При інтерпретації цих вимірювань насамперед розглядаються едафічні шкали, оскільки варіабельність грунтових властивостей проявляється на меншому масштабному рівні, ніж кліматичних. Клімат не змінюється на характерних для цієї експериментальної ділянки відстанях i, отже, чинить не диференціювальний, а нівелюючий вплив на грунт. Він, однак, серед інших факторів задає набір можливих на цій території складових частин грунту, впливаючи як прямо, так і опосередковано через інші фактори. Кореляції кліматичних шкал можуть бути результатом узгоджених трендів рослинного співтовариства, ініційованих едафічною компонентою [11].

На підставі отриманих даних можна виокремити характерні для вивчення грунту типи розподілу твердості за профілем та ті фактори навколишнього середовища, що мають значення для формування характерних типів будови грунту. У першому випадку спостерігають взаємопов'язану протилежну динаміку показників твердості грунту в шарах нижче $30 \mathrm{~cm}$ за профілем із показниками шарів, що лежать вище від виділеного блоку. Іншими словами, високі значення твердості грунту у виділеному шарі супроводжуватимуться зниженими значеннями досліджуваної ознаки вище його й навпаки. Ще однією закономірністю можна вважати таку будову грунту, коли простежують істотні відмінності твердості грунту вище та нижче від рівня 25 см від поверхні з найбільш значущими для цього типу будови значеннями твердості поверхневого шару. Формування подібної конфігурації супроводжується взаємовідношенням водно-сольового режиму досліджуваного технозему. Наступним закономірним явищем для вивченої ділянки є випадок, коли твердість грунту на рівні 10-35 см углиб профілю відрізнятиметься від навколишньої. В останньому випадку має значення кількість сонячної радіації, що припадає на ділянку, зволоженість грунту та присутність у рослинному угрупуванні степантів. Можна припускати, що фактори навколишнього середовища крім безпосередньої дії впливають на формування описаних варіантів будови грунту шляхом формування строкатості рослинного покриву. У результаті десукції вологи корінням рослин із різних частин грунтової товщі й подальшого транспіраційного ії випаровування з поверхні листя відбувається консолідація грунту та контрастне виділення грунтової будови.

Дані, представлені в табл. 4, дають загальне уявлення про взаємодію досліджуваної властивості грунту й зовнішніх чинників, що іiі формують, як про лінійну систему. Однак грунт як динамічна біокосна система не є пасивним продуктом впливу зовнішніх причин. На рис. 2 для прикладу представлено вектори екологічних факторів, таких як сольовий режим і присутність у рослинному угрупуванні різних гігроморф і їх ізолінії в просторі осей багатовимірного шкалювання. Нелінійна залежність отриманих даних від впливу вивчених екологічних факторів навіть на обмеженій відстані експериментального полігону підкреслює різну масштабність їхніх ефектів. У той час як підвищення засоленості грунту має однозначний вплив на будову грунтового профілю, кількість грунтової вологи.

Велике значення для пояснення неоднорідності властивостей грунтів має просторова структура досліджуваного явища $[6,13-15,8-12,21]$. Просторова неоднорідність грунтових властивостей обумовлена або факторами зовнішнього середовища (куди входять як біотична, так і абіотична компоненти), або внутрішніми грунтовими процесами. Для детальної характеристики екологічно обумовлених грунтових явищ потрібно визначити просторові структури й виділити процеси, що лежать у їхній основі. Має значення також масштабність прояву неоднорідності. Для досягнення цих цілей застосовано техніку просторового аналізу даних - метод головних координат матриці сусідства (PCNM - principal coordinates of neighbor matrices). Вона заснована на побудові модифікованої усі- 
ченої матриці відстаней між точками відбору проб, аналізу ії головних координат [24] і відбору PCNM-змінних, що найкраще описують властивості об’єкта дослідження [23, 25, 26, 28].
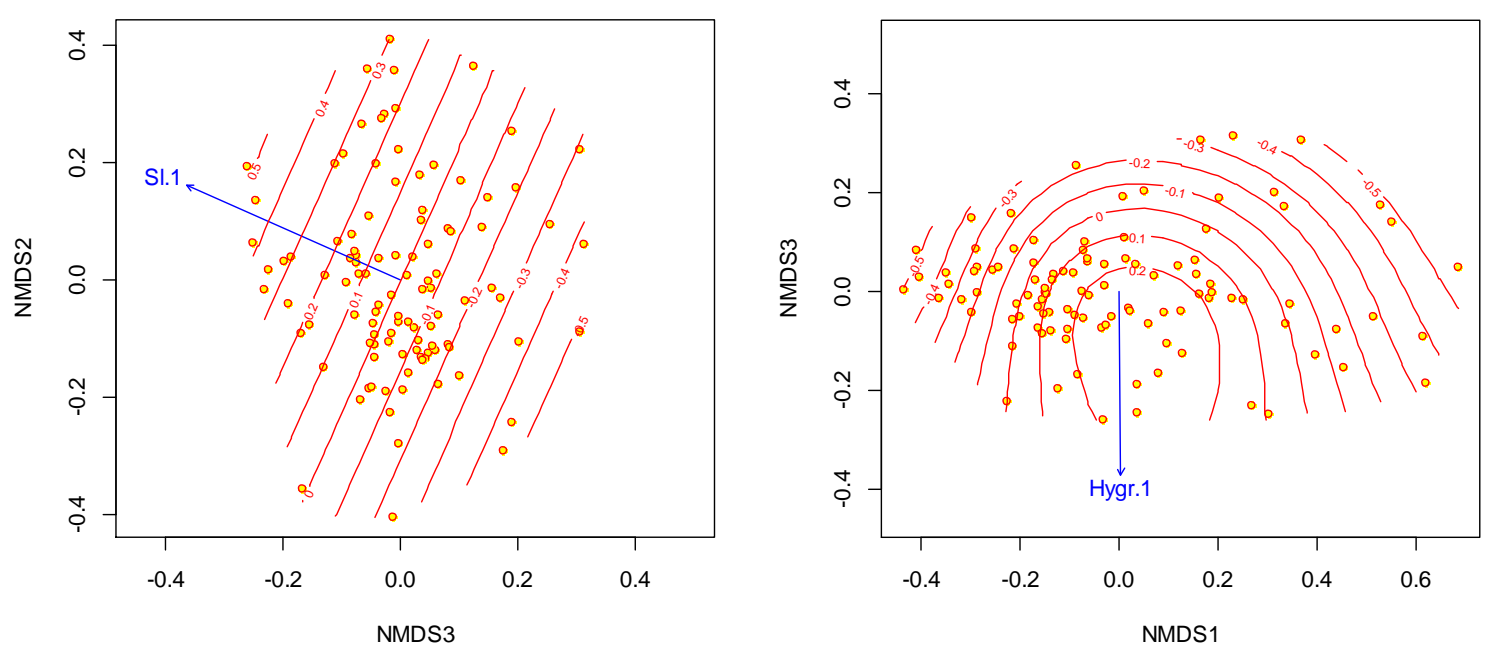

Рис. 2. Вектори екологічних факторів сольового режиму та гигроморф і їх ізолінї в просторі осей багатовимірного шкалювання

У процесі PCNM-аналізу виділено 55 PCNM-змінних, які відповідали власним числам, що перевищують 1. Ці змінні описують 66,95 \% мінливості твердості грунту (знайдено за допомогою функції RsquareAdj пакета vegan). На рис. 3 представлено наочне зображення характеру мінливості восьми найбільш інформативних із них, виокремлених за допомогою процедури прямого вибору.

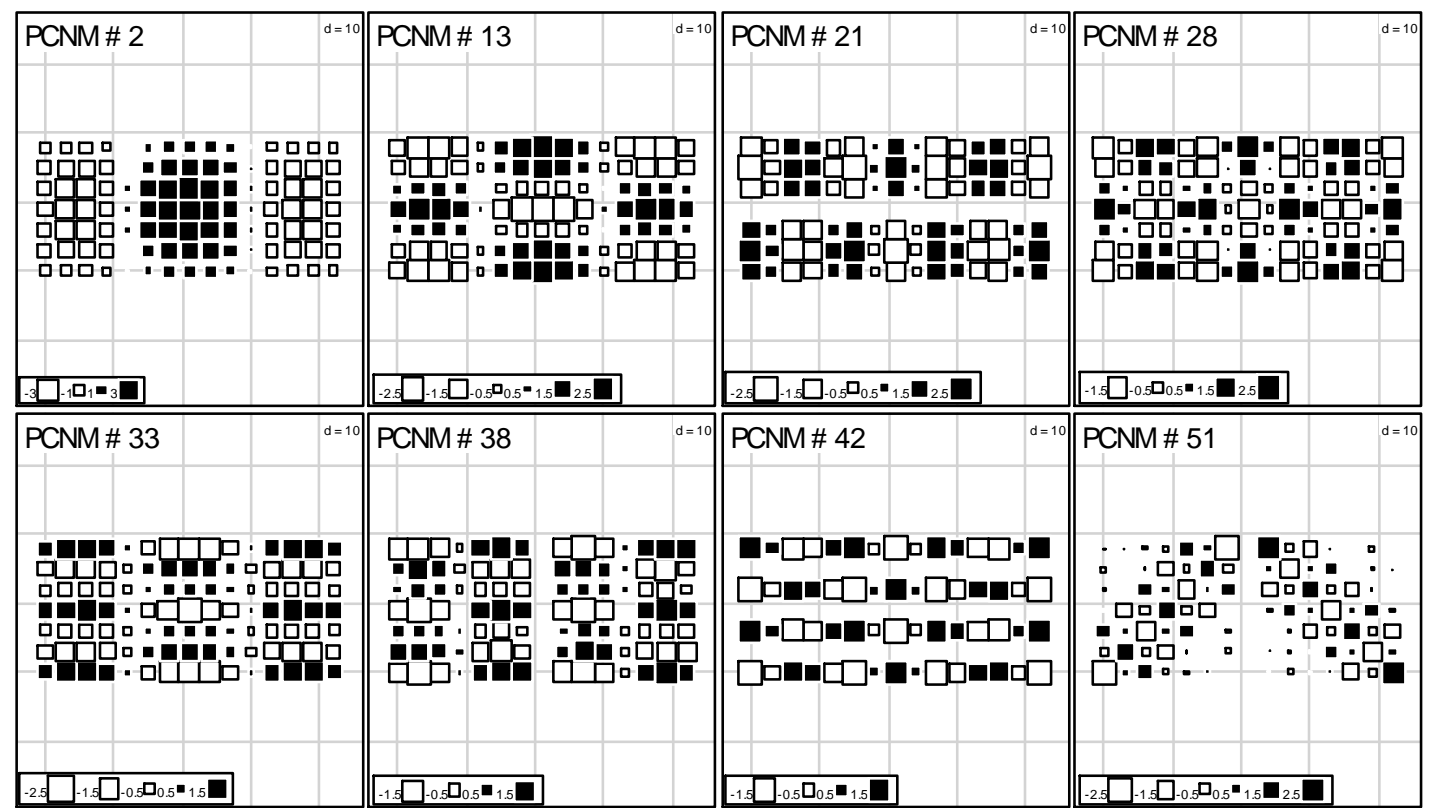

Рис. 3. Просторове розміщення значень РCNM-змінних

PCNM-змінні розміщені в порядку убування масштабу мінливості. Можна візуально виділити дві групи масштабних рівнів: 2, 13, 21, 28 РCNM-змінні представляють глобальні тренди, 33, 38, 42, 51 детальні особливості зміни твердості грунту. Змінні, залишені після прямого вибору, описують 28,93 \% мінливості твердості грунту. 
Для кожної підмножини PCNM-змінних виокремлено канонічні осі, їх просторову мінливість представлено на рис. 4. Це сукупний результат, який окреслює форми грунтової неоднорідності на різних масштабних рівнях.

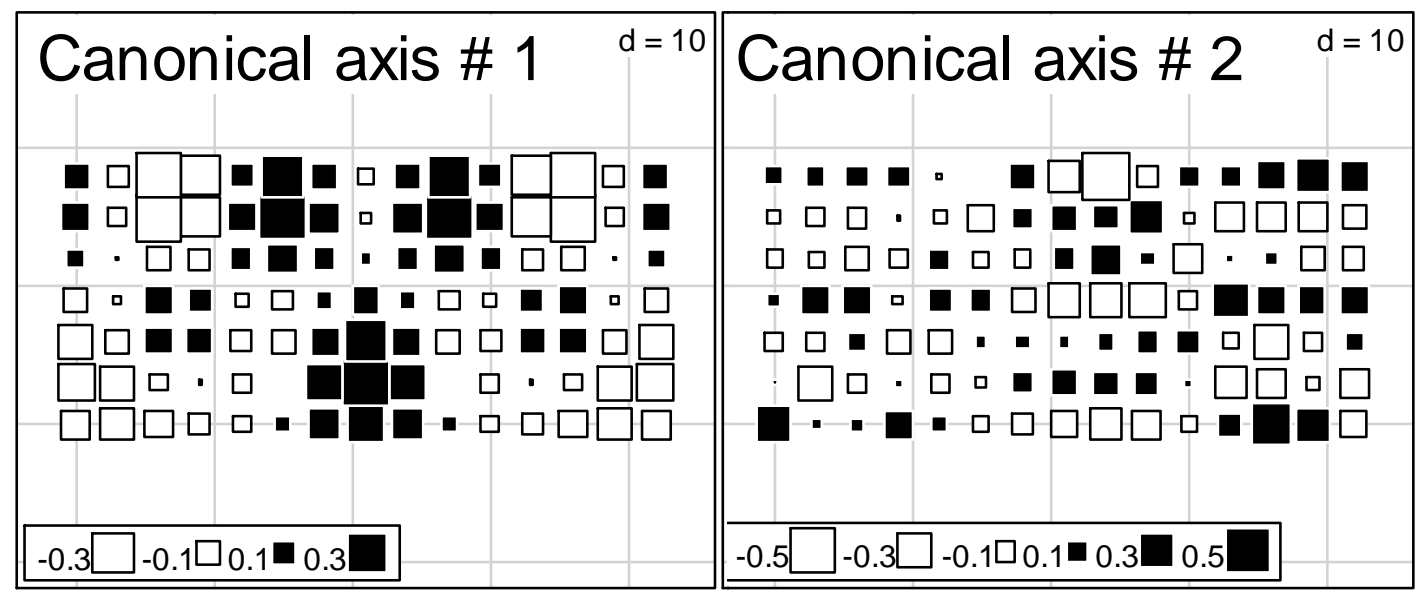

Рис. 4. Просторове розміщення канонічних осей широкомасштабних і детально масштабних компонент

Для 3'ясування характеру зв'язку канонічних осей, що відображають патерни просторової мінливості твердості грунту на різних просторових рівнях, із факторами середовища, проведено регресійний аналіз (табл. 5).

Для формування великомасштабної компоненти мінливості твердості грунту має значення трофність грунту. Неоднорідності детального масштабу маркуються сольовим режимом грунту, його кислотністю (Rc), змістом засвоюваних форм азоту (Nt), режимом освітлення (Hel) та гігроморфами. Невипадковий характер варіювання твердості грунту й залежності від зовнішніх факторів свідчить про наявність закономірності в будові грунту як природного тіла і як елемента біогеоценозу.

Таблиця 5

Регресійний аналіз зв'язку канонічних осей, що відображають патерни просторової мінливості твердості грунту на різних просторових рівнях, із факторами середовища

\begin{tabular}{|l|c|c|c|c|c|c|c|c|}
\hline \multirow{2}{*}{$\begin{array}{c}\text { Фітоінди- } \\
\text { каційні } \\
\text { шкали }\end{array}$} & \multicolumn{3}{|c|}{ Великомасштабна компонена } & \multicolumn{3}{c|}{ Детальномасштабна компонента } \\
\cline { 2 - 9 } & $\boldsymbol{\beta}$ & $\mathbf{S E}$ & $\boldsymbol{t}$-значення & $\boldsymbol{p}$-рівень & $\boldsymbol{\beta}$ & $\mathbf{S E}$ & $\boldsymbol{t}$-значення & $\boldsymbol{p}$-рівень \\
\hline $\mathrm{Hd}$ & $-0,08$ & 0,14 & $-0,61$ & 0,55 & 0,40 & 0,48 & 0,84 & 0,40 \\
\hline $\mathrm{ffl}$ & $-0,17$ & 0,19 & $-0,88$ & 0,38 & 0,46 & 0,66 & 0,69 & 0,49 \\
\hline $\mathrm{Rc}$ & 0,04 & 0,15 & 0,30 & 0,76 & 1,11 & 0,51 & 2,16 & $\mathbf{0 , 0 3}$ \\
\hline $\mathrm{Sl}$ & $-0,11$ & 0,15 & $-0,70$ & 0,48 & 1,39 & 0,53 & 2,60 & $\mathbf{0 , 0 1}$ \\
\hline $\mathrm{Ca}$ & $-0,07$ & 0,16 & $-0,44$ & 0,66 & $-0,12$ & 0,57 & $-0,22$ & 0,83 \\
\hline $\mathrm{Nt}$ & $-0,07$ & 0,14 & $-0,49$ & 0,62 & $-1,11$ & 0,49 & $-2,27$ & $\mathbf{0 , 0 3}$ \\
\hline $\mathrm{Ae}$ & 0,09 & 0,17 & 0,56 & 0,58 & 0,58 & 0,58 & 0,99 & 0,32 \\
\hline $\mathrm{Tm}$ & $-0,02$ & 0,16 & $-0,15$ & 0,88 & $-0,36$ & 0,55 & $-0,66$ & 0,51 \\
\hline $\mathrm{Om}$ & 0,20 & 0,17 & 1,17 & 0,25 & 0,09 & 0,61 & 0,15 & 0,88 \\
\hline $\mathrm{Kn}$ & $-0,02$ & 0,22 & $-0,08$ & 0,94 & 0,00 & 0,76 & 0,00 & 1,00 \\
\hline $\mathrm{Cr}$ & 0,18 & 0,15 & 1,20 & 0,24 & 0,62 & 0,54 & 1,15 & 0,25 \\
\hline $\mathrm{Lc}$ & $-0,05$ & 0,11 & $-0,46$ & 0,65 & 0,94 & 0,40 & 2,36 & $\mathbf{0 , 0 2}$ \\
\hline $\mathrm{Hygr}$ & $-0,32$ & 0,24 & $-1,31$ & 0,19 & 2,02 & 0,85 & 2,38 & $\mathbf{0 , 0 2}$ \\
\hline $\mathrm{Troph} \_\mathrm{B}$ & 0,42 & 0,21 & 2,02 & $\mathbf{0 , 0 5}$ & $-0,79$ & 0,73 & $-1,09$ & 0,28 \\
\hline $\mathrm{St}$ & $-4,25$ & 3,50 & $-1,22$ & 0,23 & $-3,20$ & 12,25 & $-0,26$ & 0,79 \\
\hline $\mathrm{Pr}$ & $-4,04$ & 3,47 & $-1,16$ & 0,25 & $-4,62$ & 12,17 & $-0,38$ & 0,71 \\
\hline $\mathrm{Hel}$ & 0,12 & 0,18 & 0,69 & 0,49 & $-0,62$ & 0,63 & $-0,98$ & 0,33 \\
\hline
\end{tabular}

Примітка. $\beta$ - стандартизований регресійний коефіцієнт, SE - стандартна помилка $\beta$. Напівжирним виділені статистично значимі кореляції $(p<0,05)$. Інші примітки див. у табл. 3. 
Грунт є об’єктом і засобом сільськогосподарського виробництва. Протягом століть накопичено дані про грунт як середовище проживання, субстраті, у якому існують живі організми та вкорінюються рослини [16]. На противагу спробам перетворення грунтознавства 3 академічної науки в теоретичний базис для сільськогосподарського виробництва ми пропонуємо подивитися на проблему 3 іншого боку. У цьому дослідженні встановлено зміну твердості грунту під впливом параметрів середовища, виражених через фітоіндикаційні шкали. Показано наявність просторової структури, виділено фактори середовища, що лежать в основі ії̈ організації. Просторову структуру розкладено на складники, які мають закономірний характер і різну масштабність своїх ефектів. У дослідженнях, опублікованих нами раніше, показано наявність просторової залежності даних твердості цього грунту й інших рекультиваційних земель $[8-10,12]$. Показано присутність закономірної морфологічної конфігурації та кореляції даних твердості з розподілом показників їі твердості, які спостерігали в попередньому році. Описано складний характер взаємодії рослинного покриву й морфологічної організації грунту, що чинить упорядкувальний вплив на грунтове тіло [9]. Існування достовірного зв'язку грунтової будови з інтенсивністю та спрямованістю екологічних факторів і структурою рослинного покриву доводить, що грунт реагує, пристосовує свої властивості до умов свого існування в біогеоценозах. Така властивість належить до фундаментальних якостей живих організмів і ставить грунт в один ряд із ними. Неповна узгодженість морфологічної та функціональної організації при вираженій ієрархічній будові - фундаментальна ознака біокосних тіл як систем, класичним представником яких $\epsilon$ грунт [1].

Висновки й перспективи подальших досліджень. Середні значення твердості грунту збільшуються з глибиною від 2,20 \pm 0,09 МПа на поверхні до 6,34 $\pm 0,24$ МПа на глибині 50 см униз за профілем. Коефіцієнт кореляції великий на поверхні (41,4 \%) знижується в шарах 5-25 см і знову зростає вглиб за профілем. Локальний максимум варіативності ознаки спостерігаємо в шарі 30-35 см нижче від поверхні (44,4 \%). Глибина, на якій у середньому трапляється твердість у 3 МПа, міститься на рівні 11,11 \pm 7,88 см нижче від поверхні.

У тривимірному екологічному просторі, визначеному за допомогою багатовимірного шкалювання, виокремлено характерні для вивченого грунту типи розподілу твердості за профілем та ті фактори навколишнього середовища, що мають значення для формування характерних типів будови грунту У першому випадку спостерігаємо взаємопов'язану протилежну динаміку показників твердості грунту в шарах, що нижчі 30 см за профілем, із показниками шарів, які лежать вище від виділеного блоку. Наступне закономірне явище для вивченої ділянки - випадок, коли простежуємо істотні відмінності твердості грунту вище й нижче від рівня 25 см від поверхні з найбільш вагомими для цього типу будови значеннями твердості поверхневого шару. Формування подібної конфігурації взаємопов'язане з водним та сольовим режимами досліджуваного технозему. Ще однією виділеною закономірністю можна вважати таку будову грунту, коли твердість на рівні 10-35 см углиб профілю відрізнятиметься від навколишньої. В останньому випадку має значення кількість сонячної радіації, що припадає на ділянку, зволоженість грунту й присутність у рослинному угрупуванні степантів.

Виділено просторові структури горизонтальної мінливості твердості грунту на різних масштабних рівнях. Для формування великомасштабної компоненти мінливості має значення трофність грунту. Неоднорідності детального масштабу маркуються сольовим режимом грунту, його кислотністю, змістом засвоюваних форм азоту режимом освітлення та співвідношенням у рослинному співтоваристві різних гігроморф.

\section{Джерела та література}

1. Арманд А. Д. Механизмы устойчивости геосистем / А. Д. Арманд. - М. : Наука, 1992. - 208 с.

2. Бельгард А. Л. Лесная растительность юго-востока УССР / А. Л. Бельгард. - Киев : Изд-во КГУ, 1950. - 263 с.

3. Бондарь Г. А. Экологическая структура растительного покрова, сформированного в результате самозарастания дерново-литогенных почв на лессовидных суглинках / Г. А. Бондарь, А. В. Жуков // Вісник Дніпропетровського державного аграрного університету. - 2011. - № 1. - С. 54-62.

4. Ворон Е. А. Свойства создаваемой почвы при послойной горнотехнической и биологической рекультивации / Е. А. Ворон // Науковий вісник НГУ, 2010. - № 5. - С. 23-28.

5. Глухов А. З. Фитоадаптивная типизация техногенных экотопов / А. З. Глухов, А. И. Хархота, С. И. Прохорова, И. В. Агурова // Промышленная ботаника. - 2012. - Вып. 12. - С. 3-11. 
6. Дмитриев Е. А. Теоретические и методологические проблемы почвоведения / Е. А. Дмитриев. - М. : ГЕОС, 2001. - $374 \mathrm{c}$

7. Стеревська Л. В. Рекультивовані грунти: підходи до класифікації і систематики / Л. В. Єтеревська, Г. Ф. Момот, Л. В. Лехцієр // Грунтознавство : наук. журн. - 2008. - Т. 9, № 3. - С. 147-150.

8. Жуков А. В. Оценка экоморфогенеза педозема и чернозема обыкновенного на основе показателей твердости / А. В. Жуков, Г. А. Задорожная / Міжвідомчий тематичний науковий збірник «Агрохімія і грунтознавство». - Х. : ННЦ «ГГА ім. О. Н. Соколовського», 2015. - Вип. 84. - С. 72-80.

9. Жуков А. В. Роль внегоризонтных почвенных морфоструктур в организации растительности дерноволитогенных почв на лёссовидных суглинках (Никопольский марганцево-рудный бассейн) / А. В. Жуков, Г. А. Задорожная // Вісник Харківського національного університету імені В. Н. Каразіна. - Серія : Біологія. - 2015. - Вип. 24. - С. 171-186.

10. Жуков А. В. Экологическое значение пространственной изменчивости твёрдости почвы в условиях природного земледелия / А. В. Жуков, Г. А. Задорожная, А. А. Демидов, Е. В. Рысина // Збірник наукових праць Уманського національного університету садівництва. Умань, 2014. - Вип. 84. - С. $21-37$.

11. Жуков О. В. Фітоіндикаційне оцінювання вимірів, одержаних за допомогою багатовимірного шкалювання структури рослинного угруповання / О. В. Жуков // Чорноморський ботанічний журнал. - 2015. T. 11, № 1. - С. 84-98.

12. Задорожна Г. О. Просторова організація дерново-літогенних грунтів на сіро-зелених глинах / Г. О. Задорожна // Біологічний вісник МДПУ ім. Б. Хмельницького, 2012. - № 1. - С. 48-57.

13. Козловский Ф. И. Теория и методы изучения почвенного покрова / Ф. И. Козловский. - М. : ГЕОС, 2003. $-536 \mathrm{c}$.

14. Медведев В. В. Структура почвы / В. В. Медведев. - Харьков, 2008. - 406 с.

15. Медведев В. В. Твердость почвы / В. В. Медведев. Харьков: Изд-во КП «Городская типография», 2009. - 152 с.

16. Мигунова Е. С. Почва как среда обитания растений / Е. С. Мигунова // Міжвідомчий тематичний науковий збірник «Агрохімія і грунтознавство». - Х. : ННЦ «ГГА ім. О. Н. Соколовського», 2015. - Вип. 81. C.112-121.

17. Михеева И. В. Пространственные флуктуации и вероятностно-статистические распределения свойств каштановых почв Кулундинской степи / И. В. Михеева // Почвоведение. - 2005. - № 3. - С. 316-327.

18. Новаковский А. Б. Методы ординации в современной геоботанике / А. Б. Новаковский // Вестник Института биологии. Коми НЦ УрО РАН. - 2008. - Вып. 132, № 10. - С. 2-8.

19. Пліско І. В. Дослідження просторової неоднорідності грунтів Михайлівської цілини / І. В. Пліско, С. Р. Трускавецький // Вісник ЦЗН АПВ Харьківської області. - 2010. - Вип. 9. - С. 217-224.

20. Реймерс Н. Ф. Экология. Теория, законы, принципы, и гипотезы / Н. Ф. Реймерс. - М. : Россия Молодая, 1975. $-367 \mathrm{c}$.

21. Самсонова В. П. Пространственная изменчивость почвенных свойств: На примере дерново-подзолистых почв / В. П. Самсонова. - М. : Изд-во ЛКИ, 2008. - 160 с.

22. Толстова Ю. Н. Основы многомерного шкалирования / Ю. Н. Толстова. - М. : КДУ, 2006. - 160 с.

23. Blanchet F. G. Forward selection of explanatory variables / F. G. Blanchet, P. Legendre, D. Borcard // Ecology. - 2008. - V. 89. № 9. - P. 2623-2632.

24. Borcard D. All-scale spatial analysis of ecological data by means of principal coordinates of neighbour matrices / D. Borcard, P. Legendre // Ecological Modelling. - 2002. - V.153, № 1-2. - P. 51-68.

25. Borcard D. Dissecting the spatial structure of ecological data at multiple scales / D.Borcard, P. Legendre, A.-J. Carol, T. Hanna // Ecology. - 2004. - V. 85, № 7. - P. 1826-1832.

26. Borcard, D. Numerical ecology in R. Sringer / D. Borcard, F. Gillet, P. Legendre. - New York, 2011. - 306 p.

27. Didukh Ya. P. The ecological scales for the species of Ukrainian flora and their use in synphytoindication / Ya. P. Didukh // Phytosociocentre. - Kyiv, 2011. - 176 p.

28. Dray S. Spatial modelling: a comprehensive framework for principal coordinate analysis of neighbour matrices (PCNM) / S. Dray, P. Legendre, PR. Peres-Neto // Ecol Model. - 2006. - V. 196. - P. 483-493.

29. Jiménez Juan J. Dissecting the multi-scale spatial relationship of earthworm assemblages with soil environmental variability / J. Jiménez Juan, T. Decaëns, P. Lavelle, J. Rossi // BMC Ecology. - 2014. - V. 14. P. 26-45.

30. Legendre P. Ecologically meaningful transformations for ordination of species data / P. Legendre, E. D. Gallagher // Oecologia. - 2001. - V. 129, № 2. - P. 271-280.

31. Medina C. Soil penetration resistance analysis by multivariate and geostatistical methods / C. Medina, H. Camacho-Tamayo Jesus, C. A. Cortes // Eng. Agric. Jaboticabal. - 2012. - V. 32, №1 . - P. 91-101.

32. Minchin P. R. An evaluation of the relative robustness of techniques for ecological ordination / P. R. Minchin // Vegetatio. - 1987. - V. 67. - P. 1167-1179. 
33. Oksanen J. Community Ecology Package. R package version 2.0-2. 2011 [Elektronik resourse]. / J. Oksanen, R. Blanchet, P. Kindt, Legendre [et al.]. - Mode of access : http://CRAN.R-project.org/package=vegan.

34. Prentice I. C. Non-metric ordination methods in ecology / I. C. Prentice // Journal of Ecology. - 1977. - V. 65. P. 85-94.

Задорожная Галина. Экологический аспект пространственной неоднородности эдафотопов техногенного происхождения. Исследована динамика пространственной неоднородности педозема участка рекультивации Никопольского марганцево-рудного бассейна в г. Орджоникидзе по показателям твердости. Проведен экоморфический анализ растительности участка. Путем неметрического многомерного шкалирования осуществлена ординация данных твердости почвы. Применен трехмерный вариант многомерного шкалирования. Выделены характерные для изученной почвы типы распределения твердости по профилю. Взаимосвязь варьирования твердости почвы и факторов окружающей среды установлена при использовании фитоиндикационных шкал. Для получения наибольшей ранговой корреляции использована матрица на основе расстояния Чао с показателями, предварительно стандартизированными к диапазонам 0-1. Установлено, что факторами, формирующими первую координационную ось экологического пространства, есть изменение твердости почвы в зависимости от глубины залегания почвенного слоя. Наблюдается взаимосвязанная противоположная динамика показателей твердости почвы в слоях ниже 30 см по профилю с показателями слоев, лежащих выше выделенного блока. Второе измерение определяют шкалы гидроморф, солевого режима и такое строение почвы, когда наблюдаются существенные различия твердости почвы выше и ниже уровня 25 см от поверхности с наибольшими значениями твердости поверхностного слоя. Наиболее высокое значение в формировании третьего измерения со стороны предикторов имеет шкала освещения. В последнем случае твердость почвы на уровне 10-35 см вглубь профиля будет отличаться от окружающей. С помощью техники пространственного анализа данных (PCNM) выделены пространственные структуры на различных масштабных уровнях и определены процессы, лежащие в их основе. Установлено, что для формирования крупномасштабных составляющих почвенной неоднородности имеет значение трофность почвы. Неоднородности детального масштаба маркируются солевым режимом почвы, его кислотностью, содержанием усваиваемых форм азота, режимом освещения и присутствием в растительной группировке различных гигроморф.

Ключевые слова: твердость почвы, экоморфический анализ, педозем, многомерное шкалирование.

Zadorozhnaya Galina. Environmental Aspect of Spatially Inhomogeneous of Technogenic Origin Edafotops. The dynamics of spatial heterogeneity of the pedozem site reclamation of the Nikopol manganese ore basin in Ordzhonikidze has been studied in terms of hardness. The ecomorphic analysis of vegetation of the section has been spent. The ordination of data of soil hardness has been realized by non-metric multidimensional scaling. The threedimensional variant of multidimensional scaling has been applied. The types of distribution of hardness in the profile typical of studied soil have been distinguished. The relationship of varying the hardness of the soil and environmental factors has been set using phytoindicative scales. For receipt most rank correlation has been used matrix based on distance the Chao with indicators pre-standardized to the range 0-1. It was established that factors forming the first coordination axis of environmental space is change the hardness of the soil, depending on the depth of the soil layer. There is interconnected opposite dynamics of soil hardness in layers of $30 \mathrm{~cm}$ below the profile with indicators of layers lying above the selected block. The scales of hydromorph, solt regime, such a structure of the soil, when there are there are significant differences in the hardness of the soil above and below the level of $25 \mathrm{~cm}$ from the surface with the most significant values of the hardness of the surface layer determine the second dimension. The highest value in the formation of the third dimension by the predictor has scale of light. In the latter case, the hardness of the soil at $10-35 \mathrm{~cm}$ depth profile will be different from surrounding. Using the technique of spatial data analysis (PCNM) has been highlighted the spatial structure at different scale levels and defined processes their underlying. It was established the trophic of soil is important for the formation of large-scale components of soil heterogeneity. The inhomogeneities of detailed scale mark by salt soil regime, its acidity, content of digestible nitrogen forms, mode lighting and presence in the group of plant different gigromorfes.

Key words: soil hardness, ecomorphic analisis, pedozems, multidimensional scaling.

Стаття надійшла до редколегії 20.03.2016 p. 